\title{
The Economic Valuation of Improved Urban Parks: A Case Study of Warda Park
}

\author{
André Melachio Tameko (Corresponding author) \\ Faculty of Economics and Management, University of Yaounde II-Soa \\ PO Box 1365, Yaounde, Cameroon \\ Tel: 237-7545-6857 E-mail: amelachio@yahoo.fr \\ Hermann Pythagore Pierre Donfouet \\ Faculty of Economics and Management, University of Yaounde II-Soa \\ PO Box 1365, Yaounde, Cameroon \\ Tel: 237-7555-7201 E-mail: donfouetz@yahoo.fr \\ Fondo Sikod \\ Faculty of Economics and Management, University of Yaounde II-Soa \\ PO Box 1365, Yaounde, Cameroon \\ Tel: 237-7750-0869 E-mail: fsikod2002@yahoo.com
}

This work was carried out with financial and scientific support from the "Nouveau Programme de Troisième Cycle Interuniversitaire (NPTCI) en Economie”.

\begin{abstract}
Urban Parks are recognized as major contributors to the physical and aesthetic quality of urban neighborhoods. Hence, there is an increasing demand for improved urban parks. The overall objective of the study is to value the preferences, attitudes and motives of Warda Park visitors for a policy that aims at endowing the park with more amenities. The contingent valuation method is used. A Logit model and a Turnbull lower bound estimator are applied in order to estimate the visitors' willingness to pay for improved urban park. The results of the study reveal that $78 \%$ of respondents are willing to pay an entrance fee that is higher than the current one if the park was endowed with more amenities. Moreover, the mean willingness to pay is 370.35 CFA francs/person for the Logit model and $351 \mathrm{CFA}$ francs/person for the Turnbull lower bound estimator. The policy implications for urban park management are discussed.
\end{abstract}

Keywords: Urban parks, Contingent valuation method, Entrance fee.

\section{Introduction}

Urban parks offer significant ecological services that have dominated the discussion concerning sustainability. The concept of sustainability has become an important model in urban planning. Sachs (1995) and Ferris et al. (2001) claimed that urban green spaces can be very positively linked to sustainability policies as urban areas around the world become the focus for population migration, and as the major source of demand on the environment. In the same way, the influence of sustainability may help to ensure that the environment, natural resources, human needs and demands are taken into consideration during the development and management of urban green spaces or landscapes (Osman and Maggie, 2006).

Urban parks are considered as important contributors to a sustainable development of cities both in developed and developing countries. They offer to residents and visitors a multitude of benefits such as recreational activities, fresh air, aesthetic, and ecological functions. The creation of urban parks is justified by the services they provide for the inhabitants of cities and also by their regulatory function on the environment. Their preservation also profit the future generations which can derive the ecological services they offer. Urban parks can sequester carbon dioxide emissions and produce oxygen (Jo, 2002). They are also a major contributor in stabilizing the urban climate, the growth of biodiversity (Konijnendijk et al., 2005) and economic development. This maybe the reason for an increasing interest for their development in urban setting. Hence, a policy that aims at improving on urban environmental amenities by the provision of public goods such as urban parks makes life in cities easier (Warner and Hefetz, 2002). The creation of urban parks has become a major concern for policymakers who are greatly interested in the importance and value of urban parks (Jacobs, 1961). Therefore, the improvement of urban parks is aimed at harmonising town planning with the environment in the quest for sustainable cities. Due to a large increase in urban population, these open spaces are increasingly in demand for 
the numerous advantages they offer. Residents of urban areas generally place a lot of importance on urban parks and green spaces and some of them are more willing to directly or indirectly fund their creation to obtain the benefits or amenities they provide (Bolund and Hunhammar, 1999). The amount that the visitors are willing to pay for an improved urban park is relevant to stakeholders when making tariff decisions.

These benefits are the possible reasons why Yaounde City Council, for the past years, has engaged in a vast environmental programme in the city, laying particular emphasis on the design of urban parks such as Warda Park. Although the Warda Park is a splendid site that enables people to come in contact with nature and benefit from other facilities it offers, there is a need for additional amenities that are in demand by the users. This high demand for the improvement of this public good is receiving renewed attention from policymakers as they strive to make this public good more attractive to residents and visitors. However, for Yaounde City Council to put in place more facilities, it is essential to assess the preferences, attitudes and motivations of the urban park's users for a policy that aims at endowing the park with more amenities. Hence, examining the demand for improved urban park using willingness-to-pay technique can provide important clues to policymakers as far as setting entrance fees is concerned. The overall objective of this study is therefore to assess the preferences, attitudes and motives of Warda Park's users for a management plan aims at endowing the Warda Park with additional facilities.

The remainder of the paper is organized as follows: Section 2 presents the methodology used to value the willingness to pay for improved urban park, while Section 3 presents the sources of the data used in the study, Section 4 considers the results of the study, and Section 5 concludes with some policy implications.

\section{Theoretical framework and estimation procedures}

According to Niewijk (1994), no market exists for much of the value people derive from the natural resources such as waterways, beaches, parks or the air itself. Without a market, there is no market price, and therefore no direct way to measure value. In response to this problem, researchers have turned to an innovative technique which uses surveys that provide a detailed description of the resource, its current condition, a hypothetical improvement on its condition or decrease in the chances of its degradation, and a way in which the person would pay for the improvement (such as increase in taxes or higher prices, monthly contribution or donation, tax reallocation, entrance fee, electricity surcharge, etc.). This technique is called the contingent valuation method (CVM) and was first used by Davis (1963).

As stated by Green and Tunstall (1999), preferences and values are the foundation of contingent valuation (CV) design. As defined by Mitchell and Carson (1989, p. 2): "the contingent valuation method uses survey questions to elicit people's preferences for public goods by finding out what they would be willing to pay for specified improvements in them. The method is thus aimed at eliciting their willingness to pay in dollars amount. It circumvents the absence of markets for public goods by presenting consumers with hypothetical markets in which they have the opportunity to buy the good in question. The hypothetical market may be modeled after either a private goods market or a political market. Because the elicited WTP values are contingent upon the particular hypothetical market described to the respondent, this approach came to be called the contingent valuation method". Although it is used in many studies, the CVM is seen by many economists and some detractors as suffering the problem that it asks a hypothetical question. The WTP estimates are inflated because respondents do not face an actual budget constraint (hypothetical bias) and because they are prone to say 'yes' too easily, perhaps just to please the interviewer (enumerator bias). Furthermore, some results are not consistent with the tenets of economic theory and are insensitive to the scope of the environmental goods. As critics of CV surveys suggest, the two main reasons for this 'yea saying' are probably the social interaction between the respondent and the enumerator, and the fact that respondents do not have to actually pay the bid amount offered. What critics often do not recognize is that $\mathrm{CV}$ researchers have developed effective ways of reducing this tendency of some respondents to say 'yes' too easily. The inclusion of the "consequentialism" script in the valuation scenario had proved to be so effective to reduce this bias (Bulte et al., 2005). This script explicitly tells the respondents they should consider that the results of the study will be made available to policymakers, and could serve as a guide for future decisions (that is, the results from the study will have an actual effect, and that they should consider this when answering the valuation question).

Many scholars have recommended to use the dichotomous choice or referendum to value public goods such as urban parks. In fact, the referendum approach mimics behaviour in regular markets where people usually purchase or decline purchase of a good at the posted price. Furthermore, the referendum format places the respondent in a familiar social context since it resembles the way that people often make actual choices regarding public programs (Carson et al., 1995). It also closely resembles people's experiences with political markets and propositions on a ballot. This approach has equally proven itself to be incentive-compatible (Bishop and Heberlein 1979; Hoehn and Randall 1987; Arrow et al., 1993). The referendum describes a choice mechanism that asks each respondent how they would vote if faced with a particular program and the prospect of paying for the program through some means such as higher taxes (Carson et al., 1995). This format is strongly recommended by the NOAA panel (Arrow et al., 1993). In the referendum format, the researcher can use both the parametric approach (PA) and the non-parametric approach (NPA) to infer the WTP. Hence, to estimate the 
WTP, two econometric methods are considered, namely: parametric and non-parametric distribution.

Following Hanemann (1984), let us assume that $\mathrm{v}(\mathrm{p}, \mathrm{q}, \mathrm{y}, \mathrm{s}, \varepsilon)$ is the indirect utility function of the individual, $\mathrm{p}$ represents the prices of the market goods, $q$ the non market good, $\varepsilon$ the stochastic component of preferences, $\mathrm{y}$ the individual's income and $\mathrm{s}$ her characteristics. Via the survey instrument, the individual is confronted with the possibility of a change from initial situation 0 to the proposed alternative 1 (that is from $\mathrm{q}^{0}$ to $\left.\mathrm{q}^{1} \succ \mathrm{q}^{0}\right)$.

In the survey, the researcher will inform the individual that this change will cost her a certain amount $A$ and she is then asked whether she would be in favor of it at that price. The individual will answer a 'yes' if only $\mathrm{v}\left(\mathrm{p}, \mathrm{q}^{1}, \mathrm{y}-\mathrm{A}, \mathrm{s}, \varepsilon\right) \geq \mathrm{v}\left(\mathrm{p}, \mathrm{q}^{0}, \mathrm{y}, \mathrm{s}, \varepsilon\right)$ and 'no' otherwise. Hence,

$$
\operatorname{Pr}\{\text { response is 'Yes' }\}=\operatorname{Pr}\left\{\mathrm{v}\left(\mathrm{p}, \mathrm{q}^{1}, \mathrm{y}-\mathrm{A}, \mathrm{s}, \varepsilon\right) \geq \mathrm{v}\left(\mathrm{p}, \mathrm{q}^{0}, \mathrm{y}, \mathrm{s}, \varepsilon\right)\right\}
$$

By using the compensating variation measure, which is the quantity $\mathrm{C}$ that satisfies:

$\mathrm{v}\left(\mathrm{p}, \mathrm{q}^{1}, \mathrm{y}-\mathrm{C}, \mathrm{s}, \varepsilon\right)=\mathrm{v}\left(\mathrm{p}, \mathrm{q}^{0}, \mathrm{y}, \mathrm{s}, \varepsilon\right)$ Thus $C=C\left(p, q^{0}, q^{1}, y, s, \varepsilon\right)$ is her maximum WTP for the change from $q^{0}$ to $q^{1}$.

It follows that she answers 'yes' if the stated price is less than this WTP, and 'no' otherwise. Hence, an equivalent condition to (1) is:

$$
\operatorname{Pr}\{\text { response is ' } Y \text { es' }\}=\operatorname{Pr}\left\{\mathrm{C}\left(\mathrm{p}, \mathrm{q}^{0}, \mathrm{q}^{1}, \mathrm{y}, \mathrm{s}, \varepsilon\right) \geq \mathrm{A}\right\}
$$

In other words, the respondent will say 'yes' when her maximum willingness to pay for the change from $q^{0}$ to $q^{1}$ is larger than or equal to the proposed bid A. For instance, when the respondent is asked whether she would pay A monetary units for a policy or a management plan aims at improving the urban park from $\mathrm{q}^{0}$ to $\mathrm{q}^{1}$, she will answer with a 'yes' if her willingness to pay is larger, or at least equal, to A.

Besides, it is assumed that $\mathrm{C}\left(\mathrm{p}, \mathrm{q}^{0}, \mathrm{q}^{1}, \mathrm{y}, \mathrm{s}, \varepsilon\right)$ is a random variable, while the respondent's WTP for the change in $q$ is something that she herself knows, it is something that the researcher does not know but treats as a random variable.

Let $\mathrm{G}_{\mathrm{c}}(\bullet)$ be what the investigator assumes is the cumulative distribution function (cdf) of C, and $\mathrm{g}_{\mathrm{c}}(\bullet)$ the corresponding density function. Then (2) becomes:

$$
\operatorname{Pr}\{\text { response is ' } Y e s '\}=1-\mathrm{G}_{\mathrm{c}}(\mathrm{A})
$$

The form of the function $G_{c}(A)$ determines the econometric model to be used. If the $G_{c}(A)$ follows logistic standard distribution and the model to estimate is linear, then (3) can be written as:

$$
\operatorname{Pr}\{\text { response is 'Yes' }\}=\frac{1+\mathrm{e}^{\delta}}{1+\mathrm{e}^{\alpha+\beta A}}
$$

Where the coefficients $\alpha$ and $\beta$ are estimated in the Logit model corresponding respectively to the constant term and the explanatory variables containing the proposed bid.

Following the formula used by Hanemann $(1984,1989)$, the truncated mean WTP for improved urban park is:

$$
\mathrm{E}(\mathrm{WTP})=-\frac{1}{\beta_{1}} \ln \left(\frac{1+\mathrm{e}^{\delta}}{1+\mathrm{e}^{\delta \beta_{1} \mathrm{M}_{\max }}}\right)
$$

Where $\beta_{1}$ is the absolute value of the estimated coefficient on the bid amount and $\delta$ is the sum of the estimated constant plus the sum of all other independent variable coefficients (independent variables which are significant) multiplied by their means. $M_{\max }$ is the maximum bid.

The non-parametric, unlike parametric, eliminates all fixed assumptions of distribution and functional forms (Greene, 2002). Thus, there are no assumptions on the distribution of WTP in a non-parametric estimation, unlike the parametric estimation. The non-parametric models are more robust and offer greater flexibility in the shape of the response function, but they provide less economic information.

The different variables used in the analysis are presented on the Table 1.

Insert Table 1 here

\section{Data sources}

A thorough face-to-face survey was administered to 160 respondents in Warda Park about their preferences and motivations about the implementation of a management plan aims at endowing the park with more attributes or 
amenities. These respondents were randomly selected. The interview was done by three (3) highly trained enumerators. The payment vehicle used was the increase in the current entrance fee to finance the management plan. Guidelines for a valid contingent valuation analysis suggested by Carson (2000), Carson et al. (2001), and Arrow et al. (1993), Whittington (1998, 2002) were followed as much as possible. Besides the "consequentialism" script developed by Bulte et al. (2005) was integrated in the valuation scenario in order to avoid the hypothetical bias, and the respondents were asked about if they agree/accept or not the proposed bid. In other words, after describing in details the proposed environmental programme, the precise wording was:

Now, I am going to ask you a question on how you would have to pay to implement the environmental programme that I earlier describe to you. But, before answering this question, keep in mind that there are other goods on which your money could be spent on, your monthly income and that the money will be solely used to implement the environmental programme. Besides, take note that the results of the study will be made available to the policymakers and could serve as guide for future decisions on the area of improved urban parks. If such a policy were put in place, would you be willing to pay CFA francs in order to implement this programme?

Before undertaking the final survey, the survey instrument was pre-tested in order to hone the questionnaire of the study and calculate the optimal bids. Hence, the following four (4) bids were calculated from the pre-test of the questionnaire: 120, 240, 360 and 480 CFA francs. The total sample was divided in four (4) sub-samples. The different bids obtained from the pre-test were randomly assigned to the respondents such as each bid is presented to an equivalent sub-sample. This is shown in Table 2.

Insert Table 2 here

\section{Empirical Results}

\subsection{Descriptive statistics}

Table 3 gives the descriptive statistics of the variables used. The respondents regularly visit the urban park in the week-end $(71.25 \%)$. The majority of the respondents have answered to have visited the urban park more than once $(73.75 \%)$. As a whole $55.63 \%$ of respondents regularly and often visit the park, and $44.37 \%$ of respondents rarely visit the park. During the survey, the respondents were called to express their degree of satisfaction regarding the facilities offer by the park. Among the individuals surveyed, $6.88 \%$ were not satisfied at all, $17.5 \%$ of respondents were a little satisfied, $61.25 \%$ were somewhat satisfied and $14.37 \%$ were very satisfied. On the question about how concerned the respondents were regarding a management plan which aims at endowing the urban park with some additional facilities, $13.75 \%$ respondents were not concerned at all, $43.75 \%$ were somewhat concerned and $42.5 \%$ were very concerned. Overall, the visitors are more attracted by the scenery. Hence the beauty of the site is the main reason for visiting the park $(90.63 \%)$. Leisurely walk is the second solicited activity $(55.63 \%)$. The park is also used for friendly discussion $(28.13 \%)$ and for reading $(20.63 \%)$.

Insert Table 3 here

In the valuation question, the four bids, 120, 240, 360 and 480 CFA francs were presented to four (4) sub-samples and they were asked to answer 'yes' or 'no' to a policy which aims at endowing the urban park with many facilities. $78 \%$ of the total respondents said they were willing to pay for the implementation of the management plan. $27.2 \%$ of total sample would be willing to pay $120 \mathrm{CFA}$ francs; $25.6 \%$ would be willing to pay $240 \mathrm{CFA}$ francs; $27.2 \%$ would pay 360 CFA francs and $20 \%$ would pay 480 CFA francs. These statistics are summarized in Table 4.

\section{Insert Table 4 here}

It turns out from Table 5 that the main reason for accepting an increase of entrance fee is that the implementation of this management plan would improve their welfare or give them more satisfaction $(38.65 \%)$. The second motive is that the policy should attract more tourists $(23.93 \%)$. The improvement of the site is the third most important motive $(23.31 \%)$.

Insert Table 5 here

Among the respondents who rejected the bids (protest bids), the main reason was that the proposed increased fee was so high for them $(67.5 \%)$. The second reason was that, they were so poor to pay such entrance fee $(20 \%)$. Besides $5 \%$ of respondents said that they would want to enjoy this public good free of charge, this is a free-rider behavior (Please refer to table 6).

Insert Table 6 here

\subsection{Results of the parametric approach}

A Logit model was used to infer the mean WTP for the improved urban park and to determine the different variables which influence the WTP. Table 7 presents the factors that influence the probability of the respondent in reporting a positive WTP.

In the economic theory, one of the fundamental hypotheses is that there must be a negative relationship between the price and the quantity. In the econometric model used, we found that the coefficient of the bid is negative that is, the proportion of visitors who have answered 'yes' to the valuation question decrease as the bid increases (or as 
the entrance fee goes up, fewer people are willing to pay the fee). This is in conformity with the microeconomic theory. Nevertheless, this variable is not significant. Besides, according to the economic theory, there must be a positive relationship between the income and the WTP. The positive sign of the coefficient of the income is in conformity with theory. Income has a positive, consistent, and statistically significant impact on the willingness of visitors to pay; this implies that the more the income of the users of the park increases, the more they are willing to pay for an improvement of the park. The coefficient of gender is positive and it is significant, that is, more male are more willing to pay than female. Age is negative and significantly correlated with the willingness to pay. Hence, the older the respondent is, the less she is likely to pay. Concerning the variables which represent the different activities that the visitors undertake at the urban park, we found that marriage, snapping pictures, friendly discussion have a positive and significant impact on the WTP. Hence, the more the respondents undertake these activities, the more they are willing to pay. Lastly, prefer days, frequency are significantly correlated with the willingness to pay. Prefer day has a negative and significant effect on the WTP. In other words, people who visit the urban park on the week-end days are less willing to pay that those who visit the urban park on the working days. One possible reason may be that, there is congestion on the week-end days. The variable frequency has a positive and significant effect on the WTP, which means that, those who visit the urban park regularly are more willing to pay for the implementation of the management plan.

Insert Table 7 here

The 'yes' or 'no' responses were translated into estimate of mean WTP. For the Logit model, Hanemann (1984, 1989) provided the WTP formula for the untruncated mean, and truncated mean. Hence, we have assumed that the WTP is non-negative (truncated mean WTP) and is between the 0 and 480 CFA francs. In table 8, the mean WTP is approximately 370.35 CFA francs/person. This information is important for the government and urban park managers to set entrance fees that will not exceed the amount visitors can afford to pay.

Insert Table 8 here

\subsection{Results of the non-parametric approach}

Haab and McConnell (2002) offer a non-parametric method of calculating the mean WTP arising from a referendum format data. In the non-parametric approach, the distribution function of the random variable producing the data need not to be specified. Table 9 shows how the mean WTP was calculated. The mean WTP is 351 CFA francs/person. This is the lower bound estimate of the WTP.

\section{Insert Table 9 here}

\section{Conclusions}

The overall objective of the study was to assess the preferences, attitudes and motives of the visitors of Warda Park for a management plan aims at endowing the park with many facilities. By using a face-to-face contingent valuation $(\mathrm{CV})$ survey we estimate two models: the parametric model and non-parametric model. In the parametric model, the Logit model reveals that the mean willingness to pay (WTP) is 370.35 CFA francs/person. The income, gender, and some activities undertaken by the visitors at the urban park such as marriage, snapping pictures, and friendly discussion are significantly correlated with the WTP. Besides, the variables prefer days and frequency were also significant and correlated with the WTP. $78 \%$ of respondents were willing to pay if such a policy is implemented. The most reason for paying was that such policy will improve their welfare. In the non-parametric model, the Turnbull estimator was used to infer the lower bound of the WTP. Hence, the mean WTP in the non-parametric model is $351 \mathrm{CFA}$ francs/person. It turns out from the results of the study that improved urban park will result in increased welfare gains for the visitors and improve the environmental quality. Accordingly, the policymakers can use this result for an adequate management of the Warda Park. First and foremost, given that people who visit the urban park on the week-end days are less likely to be willing to pay than those who visit the urban park on the working days probably because there is congestion on the week-end days, policymakers must create other urban parks which have more amenities. Secondly, given that there is high demand for improved urban park, policymakers must react by endowing the Warda Park with more amenities and support the cost of such policy by increasing the entrance fee. If such policy is applied, this will help community residents improve their health by providing a place to enjoy fresh air and exercise, help youth choose rewarding paths to adulthood by providing programs and opportunities to build physical, intellectual, emotional, and social strength. Furthermore, such policy will create long-term jobs (counselors and lifeguards) in the urban areas. Lastly, the environment in the urban area will be improved.

\section{References}

Arrow, K., Solow, P.R., Leamer, E.E., Radner, R., \& Shuman, H. (1993). Report of NOAA panel on contingent valuation method. Technical Report, 58(10), 4601-4614.

Bishop, R., \& Heberlein, T. (1979). Measuring the values of extra-market goods: Are indirect measures biased? American Journal of Agricultural Economics, 61, 926-930.

Bolund, P., \& Hunhammar, S. (1999). Ecosystems services in urban areas. Ecological Economics, 29, 293301. 
Bulte, E., Gerking, S., List, J.A., \& de Zeeuw, A. (2005). The effect of varying the causes of environmental problems on stated values: Evidence from a field study. Journal of Environmental Economics and Management, 49, 330-342.

Carson, R.T (1993). Contingent valuation: Theoretical advances and empirical tests since the NOAA panel. American Journal of Agricultural Economics, 79 (5), 1501-1507.

Carson, R.T. (2000). Contingent valuation: A user's guide. Environmental Science and Technology, 34, 1413-1418.

Carson, R.T., Flores, N.E., \& Meade, N.F. (2001). Contingent valuation: controversies and evidence. Environmental and Resource Economics 19(2), 173-210.

Carson, R.T., Hanemann, W.M., Kopp, R.J., Krosnik,, Mitchell, R.C., Presser, S., Ruud, P.A., Smith, V. K., Conaway, M., \& Martin, K. (1995). Referendum design and contingent valuation: The NOAA panel's no vote recommendation. Discussion paper 96-05, Washington, D.C.: Resources for the Future.

Davis, R.K. (1963). Recreation planning as an economic problem. Natural Resources Journal, 3, 239-249

Ferris, J., Norman, C., \& Sempik, J. (2001). People, land and sustainability: Community gardens and the social dimension of sustainable development. Social Policy and Administration. 35(5), 559-568.

Green, C. \& Tunstall, S. (1999). A psychological perspective. In I.J. Bateman, \& K.C. Willis, (Eds.), Valuing Environmental Preferences: Theory and Practice of Contingent Valuation Method in the US, EU, and Developing Countries. Oxford, UK: Oxford University Press.

Greene, W.H. (2002). Econometric Analysis. 5th ed. Prentice Hall, New York.

Haab, T. C., \& McConnell, K. E. (2002). Value environmental and natural resources: The econometrics of non-market valuation. Cheltenham, UK: Edward Elgar.

Hanemann, M. W. (1984). Welfare evaluations in contingent valuation experiments with discrete response. American Journal of Agricultural Economics, 66, 332-341.

Hanemann, M. W. (1989). Welfare evaluations in contingent valuation experiments with discrete response data: reply. American Journal of Agricultural Economics, 71, 1057-1061.

Hoehn, J.P., \& Randall, A. (1987). A satisfactory benefit cost indicator from contingent valuation. Journal of Environmental Economics and Management, 14, 226-247

Jacobs, J. (1961). The death and life of great American cities, Harmondsworth, UK: Penguin Books.

Jo, H. (2002). Impacts of urban greenspace on offsetting carbon emissions for middle Korea. Journal of Environmental Management, 64, 115-126.

Konijnendijk, C., Nilsson, K., Randrup, T., \& Schipperijn, J. (2005). Urban forests and trees -A reference book. Springer.

Mitchell, R.C., \& Carson, R.T. (1989). Using surveys to value public goods: The contingent valuation method. Washington DC: Resources for the Future.

Niewijk, R. K. (1994). Misleading quantification: The contingent valuation of environmental quality. Regulation, 60(1), 60-71.

Osman, M. T., \& Maggie, H. R. (2006). Sustainable urban landscapes: Making the case for the development of an improved management system. International Journal on Sustainable Tropical Design Research \& Practice, 1 (1), 17-24.

Sachs, A. (1995). Eco-Justice: linking human rights and the environment. Worldwatch Paper 127. Washington DC.

Warner, M. E. \& Hefetz, A. (2002). Applying market solutions to public services: An assessment of efficiency, equity and voice. Urban Affairs Review, 38(1), 70-89.

Whittington, D. (1998). Administering contingent valuation surveys in developing countries. World Development, 26, 21-30.

Whittington, D. (2002). Improving the performance of contingent valuation studies in developing countries. Environmental and Resource Economics, 22, 323-367. 
Table 1. Dichotomous choice contingent valuation model variables

\begin{tabular}{|c|c|}
\hline Variables & Definition \\
\hline INC & $\begin{array}{l}\text { Monthly income of the respondent, } 1 \text {, if respondent's monthly income is } \\
\text { above } 75000 \text { CFA francs , } 0 \text { otherwise }\end{array}$ \\
\hline Bid & $\begin{array}{l}\text { Start prices presented to the respondents Ranging from } 120,240,360 \text { to } 480 \\
\text { CFA francs }\end{array}$ \\
\hline WTP & $\begin{array}{l}\text { Dichotomous variable indicating whether or not the respondent accepts the } \\
\text { offered Bid ; } 1=\text { accept and } 0 \text {, otherwise }\end{array}$ \\
\hline GEND & Gender; 1 , if respondent is male, 0 otherwise \\
\hline AGE & Age in years \\
\hline NCHILD & Number of children \\
\hline MATSTA & Marital status; 1 , if respondent is single, 0 otherwise \\
\hline Educ & $\begin{array}{l}\text { Education level divided in three groups: } \\
\text { - No schooling (reference modality) } \\
\text { - Prim educ, } 1 \text {, if the respondent has the FSLC (First school-leaving } \\
\text { certificate) and } 0 \text { otherwise } \\
\text { - Secon educ, } 1 \text {, if the respondent has a certificate of the secondary school (or } \\
\text { has attained secondary education) but did not attain university education, } 0 \\
\text { otherwise. } \\
\text { - Univ educ, } 1 \text {, is the respondent has a university certificate (or she is currently } \\
\text { a university student), } 0 \text { otherwise }\end{array}$ \\
\hline Employed & $\begin{array}{l}\text { Whether the respondent is employed or not in the formal/ informal sector. } \\
1=\text { employed and } 0 \text {, otherwise }\end{array}$ \\
\hline Leisurely walk & $\begin{array}{l}\text { Takes } 1 \text { if the respondent used to come to the park for leisurely walk, } 0 \\
\text { otherwise }\end{array}$ \\
\hline $\begin{array}{l}\text { Academic } \\
\text { excursion }\end{array}$ & $\begin{array}{l}\text { Takes } 1 \text { if the respondent used to come to the park for academic excursion, } 0 \\
\text { otherwise }\end{array}$ \\
\hline $\begin{array}{l}\text { Friendly } \\
\text { discussion }\end{array}$ & $\begin{array}{l}\text { Takes } 1 \text { if the respondent used to come to the park for friendly discussion, } 0 \\
\text { otherwise }\end{array}$ \\
\hline Reading & Takes 1 if the respondent used to come to the park for reading , 0 otherwise \\
\hline Marriage & $\begin{array}{l}\text { Takes } 1 \text { if the respondent used to come to the park for marriage activities, } 0 \\
\text { otherwise }\end{array}$ \\
\hline Beauty scenery & $\begin{array}{l}\text { Takes } 1 \text { if the respondent used to come to the park for beauty scenery, } 0 \\
\text { otherwise }\end{array}$ \\
\hline $\begin{array}{l}\text { Snapping } \\
\text { pictures }\end{array}$ & $\begin{array}{l}\text { Takes } 1 \text { if the respondent used to come to the park for snapping pictures, } 0 \\
\text { otherwise }\end{array}$ \\
\hline Prefer days & $\begin{array}{l}\text { days of weekend, } 1 \text {, if the respondent used to visit the park during the days of } \\
\text { the weekend }\end{array}$ \\
\hline Frequency & Takes 1 if the respondent most often visit the park, 0 otherwise \\
\hline $\begin{array}{ll}\text { Degree } \\
\text { satisfaction }\end{array}$ of & Takes 1 if the respondent is not satisfied at, 0 otherwise \\
\hline
\end{tabular}


Table 2. Allocation of the bids in the sub-sample

\begin{tabular}{|l|l|l|}
\hline Bids (CFA francs) & Counts ni & Percentage \\
\hline 120 & 40 & 25 \\
\hline 240 & 40 & 25 \\
\hline 360 & 40 & 25 \\
\hline 480 & 40 & 25 \\
\hline Total & 160 & 100 \\
\hline
\end{tabular}

Table 3. Descriptive statistic of the variables used

\begin{tabular}{|l|l|l|l|l|}
\hline Variables & Mean & Variance & Min & Max \\
\hline INC & 0.275 & 0.20062893 & 0 & 1 \\
\hline Bid & 300 & 18113.2075 & 120 & 480 \\
\hline WTP & 0.78125 & 0.17197327 & 0 & 1 \\
\hline GEND & 0.49375 & 0.25153302 & 0 & 1 \\
\hline AGE & 27.05625 & 69.58 & 15 & 64 \\
\hline NCHILD & 0.75 & 2.06289308 & 0 & 9 \\
\hline MATSTA & 0.825 & 0.14528302 & 0 & 1 \\
\hline Prim educ & 0.04375 & 0.04375 & 0 & 1 \\
\hline Secon educ & 0.53125 & 0.25058962 & 0 & 1 \\
\hline Univ educ & 0.4125 & 0.24386792 & 0 & 1 \\
\hline Employed & 0.3125 & 0.21619497 & 0 & 1 \\
\hline Leisurely walk & 0.55625 & 0.24838836 & 0 & 1 \\
\hline Academic excursion & 0.1625 & 0.13694969 & 0 & 1 \\
\hline Friendly discussion & 0.275 & 0.20062893 & 0 & 1 \\
\hline Reading & 0.2125 & 0.16839623 & 0 & 1 \\
\hline Marriage & 0.0375 & 0.03632075 & 0 & 1 \\
\hline Beauty scenery & 0.91875 & 0.07511792 & 0 & 1 \\
\hline Snapping pictures & 0.08125 & 0.07511792 & 0 & 1 \\
\hline Prefer days & 0.7125 & 0.20613208 & 0 & 1 \\
\hline Frequency & 0.44375 & 0.24838836 & 0 & 1 \\
\hline Degree of satisfaction & 0.075 & 0.06981132 & 0 & \\
\hline
\end{tabular}

Table 4. Willingness to pay responses by fee amount

\begin{tabular}{|l|l|l|l|l|l|}
\hline Bids (CFA francs) & Yes & \% Yes & No & \% No & Total \\
\hline 120 & 34 & 27.2 & 6 & 17.1 & 40 \\
\hline 240 & 32 & 25.6 & 8 & 22.9 & 40 \\
\hline 360 & 34 & 27.2 & 6 & 17.1 & 40 \\
\hline 480 & 25 & 20 & 15 & 42.9 & 40 \\
\hline Total & 125 & 78 & 35 & 22 & 160 \\
\hline
\end{tabular}


Table 5. The different reasons for paying

\begin{tabular}{|l|l|}
\hline Reasons for paying & Percentage \\
\hline The project is ecologic & 12.27 \\
\hline More satisfaction & 38.65 \\
\hline More tourists & 23.93 \\
\hline Improvement of the site & 23.31 \\
\hline The amount is quite acceptable & 1.84 \\
\hline Total & 100 \\
\hline
\end{tabular}

Table 6. The different reasons for refusing to pay (protest bids)

\begin{tabular}{|l|l|}
\hline Reasons for not paying & Percentage \\
\hline The bid is so high & 67.5 \\
\hline I am so poor to pay such amount & 20 \\
\hline I don't like this governmental project & 5 \\
\hline I would like to have all these advantages free of charge & 5 \\
\hline My vote will not count & 2.5 \\
\hline Total & 100 \\
\hline
\end{tabular}

Table 7. Logit model (parametric model with covariates)

\begin{tabular}{|l|l|l|}
\hline Variable name & Coefficients & Standard errors \\
\hline Constant & 2.995661 & 2.995661 \\
\hline Bid & -0.0021181 & 0.0020443 \\
\hline INC & $2.381557^{* * *}$ & 0.6296362 \\
\hline Age & $1.031387^{*}$ & 0.6005666 \\
\hline Prim educ & $-0.1291936^{* * *}$ & 0.0454488 \\
\hline Secon educ & 2.83452 & 1.765925 \\
\hline Univ educ & 2.282312 & 1.494686 \\
\hline NCHILD & 1.38783 & 1.387129 \\
\hline Employed & -0.0586613 & 0.2153453 \\
\hline MATSTA & -0.2953288 & 0.5752354 \\
\hline Leisurely walk & -0.8567426 & 0.7327141 \\
\hline Academic excursion & 0.5715804 & 0.5056579 \\
\hline Reading & 0.5819665 & 0.8697228 \\
\hline Marriage & 0.4717673 & 0.5920738 \\
\hline Beauty scenery & $2.381071^{* *}$ & 1.062861 \\
\hline Snapping pictures & 0.1405051 & 0.9227087 \\
\hline Friendly discussion & $2.428315^{* * *}$ & 0.7851678 \\
\hline Prefer days & $1.501953^{* *}$ & 0.7069249 \\
\hline Frequency & $-1.42954^{* *}$ & 0.6866968 \\
\hline Degree of satisfaction & $0.8714451^{*}$ & 0.5053741 \\
\hline
\end{tabular}

$* * *, * *, *$ : indicate significant at $1 \%, 5 \%$ and $10 \%$ respectively. 
Table 8. Truncated mean WTP estimates

\begin{tabular}{|l|l|l|l|}
\hline Variables & Coefficients (1) & Means (2) & $(1)^{*}(2)$ \\
\hline Prefer days & -1.42954 & 0.7125 & -1.01854725 \\
\hline Frequency & 0.8714451 & 0.44375 & 0.38670376 \\
\hline INC & 2.381557 & 0.275 & 0.65492818 \\
\hline GEND & 1.031387 & 0.49375 & 0.50924733 \\
\hline Age & -0.129194 & 27.05625 & -3.49549434 \\
\hline Friendly discussion & 1.501953 & 0.275 & 0.41303708 \\
\hline Marriage & 2.381071 & 0.0375 & 0.08929016 \\
\hline Snapping pictures & 2.428315 & 0.08125 & 0.19730059 \\
\hline Constant & 2.995661 & 1 & 2.995661 \\
\hline Total $(\delta)$ & - & - & 0.73212651 \\
\hline
\end{tabular}

$\beta_{1}=-0.002118$ and $M_{\max }=480$, then $\mathrm{E}(\mathrm{WTP})=370.35$

Table 9. Turnbull estimates

\begin{tabular}{|c|c|c|c|c|c|}
\hline Bid price & Number of No's & Number offered & Unrestricted & \multicolumn{2}{|c|}{ Turnbull (pooled) } \\
\hline $\mathrm{t}_{\mathrm{j}}$ & $\mathrm{N}_{\mathrm{j}}$ & $\mathrm{T}_{\mathrm{j}}$ & $\mathrm{F}_{\mathrm{j}}=\frac{\mathrm{N}_{\mathrm{j}}}{\mathrm{T}_{\mathrm{j}}}$ & $\mathrm{F}_{\mathrm{j}}^{*}$ & $\mathrm{f}_{\mathrm{j}}^{*}$ \\
\hline $0-120$ & 6 & 40 & 0.15 & 0.15 & 0.15 \\
\hline $120-240$ & 8 & 40 & 0.2 & 0.175 & 0.025 \\
\hline $240-360$ & 6 & 40 & 0.15 & Pooled & Pooled \\
\hline $360-480$ & 15 & 40 & 0.375 & 0.375 & 0.2 \\
\hline 480 and above & - & - & 1 & 1 & 0.625 \\
\hline
\end{tabular}

$E_{\text {inf }}(W T P)=\sum_{j=0}^{M_{\max }} t_{j} f{ }_{j+1}$

Where $E_{\text {inf }}\left(\right.$ WTP) is the lower bound estimate, $t_{j}$ is the entrance fee amount, $f{ }_{j+1}$ is the percentage of respondents who stated they would not pay the fee at ${ }_{j+1}$, and $M_{\max }$ is the maximum fee amount. Hence: $\mathrm{E}_{\text {inf }}(\mathrm{WTP})=0 * 0.15+120 * 0.025+240 * 0.2+480 * 0.625=351$ 